\title{
『大毘婆沙論』における『法縚足論』の 引用について
}

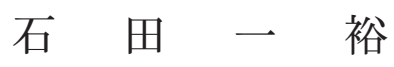

\section{1.はじめに}

本稿の目的は、まず『大毘婆沙論』における『法蘊足論』の引用状況を 明らかにすること、次に個々の引用の考察、検討を通して、『大毘婆沙論』 が『法蘊足論』をどのように扱っているかを明らかにすることである。こ の目的を達成するために、『大毘婆沙論』に『法藴足論』の引用として明 示される文言をすべて抽出し、それらを検討する。

\section{2. 問題の所在}

有部論書としての「六足発智論」には、「有部における最古かつ最権威 的な一団の諸聖典」（渡辺楳雄『有部阿毘達磨論の研究』p.44）という理 解と、「「六足・発智」といら考え方は、特に、有部論書を成立史的に見よ らとする場合、余り意味を持ためもの」（桜部建『俱舎論の研究 根品・ 界品』p.44）といら理解とがある。「六足・発智」をどのように理解する かは研究の立場によって相違が生じるかもしれないが、有部の教理学に とって「大毘婆沙論から顕宗論に至る諸論の中に引かれる有部論書が、ほ とんど、界身論を除く五論および発智論に限られている事実は、確かにそ れらの論の重要性を証している」（桜部前掲書 p.44）ことは事実として認 められるところである。ただし、その引用が「ときによれば、経立二蔵の 諸聖典からの引用以上の、畢竟ずるに最権威的なるものとして然せられて いることもはなはだ夥多なるもの」（渡辺前掲 p.44）といら判断は、全引 用の用例を精査した上でなければ下すことはできない。そこで私は、一ま ず『大毘婆沙論』に限って六足論の引用状況をすべて調査し、その精査を 行なって、この様な判断が正確かどうかを見極めたい。より正確には「と きによれば」が意味するところの頻度を正確に判定したい。 
本稿はその作業の第一となるもので、『大毘婆沙論』における『法藴足 論』の引用を考察する。

\section{3.『大毘婆沙論』における六足論の引用状況}

具体的な考察の前に『大毘婆沙論』が六足論の名称が何回表われている かを確認したい。『大毘婆沙論』において六足論の名称は以下の回数見い だせる。

『集異門足論』・・39回

『施設足論』・・・135回

『品類足論』・・・109回 ${ }^{1}$
『法蘊足論』・・9回

『界身足論』・・・0回

この回数は単純にその名称が表われるものであり、そのすべてに引用文 が付随するわけではない2。これは、あくまで各論書の名称が表われる回 数であるが、『大毘婆沙論』が六足論を等しく引用しているのではないこ とが予想される。特に『界身足論』は名称が見いだせず、『大毘婆沙論』 の編纂者にとって引用の必要がない論書と見なされていたか、あるいはそ もそも存在を知らなかったと推測できる。その他の論書に関しても、『法 藴足論』と『施設足論』には100回以上の違いがある。このような相違は なぜ生まれるのであろらか。私はこの問に対して、個々の引用を考察する ことで回答を与えることができるだろうと予想している。

\section{4.『大毘婆沙論』における『法蘊足論』の引用}

『大毘婆沙論』において「法藴足論」といら名称は 9 回確認できるが、 これは五つの用例に大別できる。以下、その五つをそれぞれ紹介し、考察 を加えていく。

\section{4-1. 用例1)一縁起・縁已生法について言及一}

『大毘婆沙論』においてはじめに考察される『法蘊足論』の引用は、縁 起と縁已生法についての言及する箇所である。以下に『大毘婆沙論』、そ 
の和訳、『阿毘量毘婆沙論』対応箇所、『法蘊足論』該当箇所、その和訳の 順に本文を提示していく。

\section{『大昆婆沙論』（大正27・p.118b）}

『集異門論』及『法蘊論』俱作是説。「若無明生行。決定安住不雜 亂者。名縁起法。亦名縁已生法。若無明生行。不決定不安住而雜亂 者。名縁已生法。非縁起法。乃至生 除老死應知亦爾。」

\section{上記和訳}

『集異門論』および『法蘊論』はともに以下のような説明をしてい る。「もしも無明が行を生じる場合に、決定し安住して乱れないな らば、縁起法と名づけ、また縁已生法と名づける。もしも無明が行 を生じる場合に、決定せず安住せずに乱れているならば、縁已生法 とは名づけるが、縁起法ではない。乃至、生が老死を生ず場合まで、 同様に知るべきである。」

\section{『阿毘曇毘婆沙論』対応箇所（大正28・p.93b）}

如法身經所説。諸無明決定生行不相離常相隨。是名縁起縁生。若無 明不決定生行。或時相離不相隨。是名縁生非縁起。乃至生老死。亦 應如是説。

\section{『法藴論』該当箇所（大正 $26 \cdot p .505 b$ 。下線部は『大毘婆沙論』の 引用に相当する部分。以下同)}

此中緣起緣已生法。其體雖一。而義有異。謂或有緣起非緣已生法。 或有緣已生法非緣起。或有緣起亦緣已生法。或有非緣起亦非緣已生 法。或有緣起非緣已生法者無也。或有緣已生法非緣起者。謂無明行 識名色六處觸受愛取有生老死。或有緣起亦緣已生法者。謂生定能生 於老死。如是生支。定能為緣。是緣起性。及緣已生法性。如是有取 愛受觸六處名色識行無明。應知亦爾。非緣起非緣已生法者。謂除前 相。

\section{上記和訳}


この〔経に説く〕なかで、縁起〔法〕と縁已生法とは、その実態は 同一であるが、その意味には相違がある。すなわち、ある〔法の〕 場合には、縁起であるが、縁已生法ではない。ある〔法の〕場合に は、縁已生法であるが、縁起ではない。ある〔法の〕場合には、縁 起であり、また縁已生法でもある。ある〔法の〕場合には、縁起で もなく、また縁已生法でもない。「ある〔法の〕場合には、縁起で あるが、縁已生法ではない」とは、そのような法はない。「ある 〔法の]場合には、縁已生法であるが、縁起ではない」とは、すな わち無明・行・識・名色・六處・觸・受・愛・取・有・生・老死な り。「ある〔法の〕場合には、縁起であり、また縁已生法でもある」 とは、すなわち、生は安定してよく老死を生じ、このような生支は 安定してよく縁となるので、これは縁起性であり、および縁已生法 性でもある。同様に有・取・愛・受・觸・六處・名色・識・行・無 明についても、知るべきである。また「縁起でもなく、また縁已生 法でもない。とは、すなわち前に説明したもの以外である。

この箇所は『大毘婆沙論』二三において、『発智論』一の「一補特伽羅

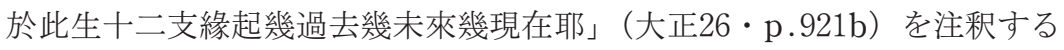
中に表われるものであるが、傍論（因論生論〔論により論を生じる〕）に 位置づけられる箇所である。『大毘婆沙論』は『発智論』の当該箇所に対 して、二三巻と二四巻の三分の二ほどの分量を以て註勫を行ない、その中 には本文の注釈から派生した様々な議論がなされている。この議論の中で、 上記『法蓝足論』の一文は、「問緣起法與緣已生法差別云何」（大正27 ・ p.118a）という問に対する、回答の一つとして紹介されている。回答の 一つというのは、『大毘婆沙論』はこの問に対して様々な論書や論師の説 をもって回答を提示しているらちの一つといらことである。『法藴足論』 以外の説を列挙すると『品類足論』、有余師、脇尊者、尊者妙音、尊者満 望、尊者世友、大徳、尊者覚天となる。これは『大毘婆沙論』の当該箇所 が、縁起法と縁已生法について可能な限りの学説を列挙することで説明を 試みている個所といらことができよう。つまり『法蓝足論』の所説は、そ の他の学説と同様に、諸説ある中の一つとして扱われていると指摘するこ とができる。 


\section{4-2. 用例(2)一尋と伺の性質についての譬喻—}

第二の用例は、尋と伺の性質を譬喻で説明する際のものである。

\section{『大毘婆沙論』(大正27・p.219a-b)}

『法藴論』説。如天震雷人吹貝等。初大後微。尋伺亦爾。又作是説。 如鳥飛空鼓翼翔惹。前泩後細尋伺亦爾。

\section{上記和訳}

『法藴論』は〔次のように〕説いている。「天の震雷や、人が貝を 吹く時などに、初めは〔音が〕大きく、後になると微かになるよう に、尋と伺もまたそのようなものである。」あるいはまた、次の 〔ようにも〕説いている。「鳥が空を飛ぶときに、翼をはばたかせ て、飛び立つときに、初めは〔羽の動きが〕激しく、後には細かく なるように、尋と伺もまたそのようなものである。」

\section{『阿毘曇毘婆沙論』対応箇所（大正28・p.169a-b）}

法身經亦説。如天雷時。聲有庇細。覺所作當知如庇聲。觀所作當知 如餘細聲。銅鈴銅器。出鹿細聲。亦如是。亦如鳥飛虚空。鼓其兩翼。 當知如覺。踊身得去。當知如觀。

\section{『法䔋論』該当箇所（大正 $26 \cdot p .483 b ）$}

尋與伺。何差別。令心庇性是尋令。心細性是伺。此復如何。如打鍾 時。庇聲暫發。細聲隨轉。庇聲喻尋。細聲喻伺。搖鈴扣鉢。吹螺擊 鼓。放箭震雷。庇細二聲為喻亦爾。又如衆鳥飛翔虛空。鼓翼踊身。 方得隨意。鼓翼喻尋。踊身喻伺。是謂尋伺二相差別。

\section{上記和訳}

尋と伺とはどのような区別があるのだろらか。心を粗雑な性質にさ せるものが尋なであり、心を繊細な性質にさせるものが伺である。 それはどのようなことであろらか。〔例えば〕鍾を打つ時に、〔初め は〕荒々しい音がしばらくなって、〔その後に〕小さな音に変って いくようなものである。荒々しいは尋を譬えたもので、小さな音は 
伺を譬えたものである。〔あるいはまた〕鈴を摇らし、鉢を吒き、 螺を吹き、鼓を撃ち、弓矢を放ち、雷がなる時に、荒々〔しい音] と小〔さな音〕の二つの音を譬えとしても同じようなものである。 また、抽の鳥が大空を飛翔して翼をはばたかせ、身を踊して、 まさに意のままに〔飛ぶことを〕得るようなものである。翼をはば たかせることを尋に譬え、身を踊すことを伺に譬えるのである。こ れが尋と伺との二の特徴の区別である。

これは『大毘婆沙論』四二における議論であり、『発智論』の「尋伺何 差別。答心庇性名尋。心細性名伺。是謂差別」（大正 $26 \cdot p .927 b ） に$ 対す る注釈に当たる部分である。有部は尋（vitarka）と伺（vicāra）を心の 粗さ（㢈性：audārikatā）と纎細さ（細性：sūkșmatā）と定義するが、 あい反する二つの心の働きがどうして一つの心に起こりらるかについては、

『大毘婆沙論』の当該箇所や『俱舎論』根品（AKBh.pp.60-61）などで 議論されるところである。これを問題意識としつつ、この箇所は譬喻に よってそれに答えようとしている。『法蘊足論』が引用される直接の問い は「問尋伺庇細其相如何。というもので、これに対して『法藴足論』も 含めて六つの譬喻が紹介される。『大毘婆沙論』によれば、このうち五つ は「彼說皆顯尋伺不俱作用增時有前後故（彼の説は、皆、尋伺の俱ならざ ることを顕す。作用增す時、前後有るが故に）」（大正 $27 \cdot \mathrm{p} .219 \mathrm{~b} ）$ であ り、尋と伺とが俱に働かないことを示すものである。尋と伺とが俱に働く 譬喻は『俱舎論』にも用いられるものであり、それは、バター（熟酥）を 冷水の上に置くといらもので、上からは日光がバターを溶かし、下からは 水が冷やすので、バターが溶けるのでもなく、固まるでもない状態となる。 この例えにおいては、尋伺が日光と冷水に心がバターに譬えられている。

『大毘婆沙論』の評価、ならびに『俱舎論』が『法藴足論』の譬喻を用い ないことから、これが一心に尋伺の両方が存在することの説明としては、 主流とならなかったことが推測される。

\section{4-3. 用例(3)一中有と五趣の関係について一}

第三の用例は、中有と五趣の関係についての言及である。 


\section{『大毘婆沙論』（大正27・p.358b）}

『法蘊論』説復云何通。如彼論説。「云何眼界。答四大種所造清淨 色是眼。及眼根眼處眼界地獄傍生鬼天人眼。修所成眼及中有眼。」

\section{上記和訳}

また『法蘊論』の説をどのように理解すべきであろうか。彼の論に は次のように説かれている。「云何が眼界なりや。答う。四大種所 造の清淨色の、是れ眼、及び眼根、眼處、眼界にして、地獄、傍生、 鬼、天、人の眼と、修所成の眼と、及び中有の眼なり。」

\section{『阿昆曇昆婆沙論』対応箇所（大正28・p.265b）}

攝何等。不攝中有。法身經説。復云何通。如説云何眼界。答言。四 大及清淨造色眼眼根眼入眼界。若地獄餓鬼畜生人天眼。若修得眼。 若中有眼。

\section{『法蘊論』該当箇所（大正 $26 \cdot p .498 b-c$ 。該当箇所より対応部分の みを抽出）}

云何眼根。（中略）謂四大種所造淨色。或地獄。或傍生。或鬼界。 或天或人或中有。及脩所成。（中略）名眼。名眼處。名眼界。名眼 根・・・

\section{上記和訳}

如何なるものが眼根であろらか。（中略）すなわち四大種によって 造られた浄色であって、あるいは地獄、あるいは傍生、あるいは鬼 界、あるいは天、あるいは人、あるいは中有、および脩所成である ものを (中略)、眼と名づけ、眼處と名づけ、眼界と名づけ、眼根 と名づけ・・・

ここで『大毘婆沙論』が『法藴足論』の引用として紹介するのは「云何 眼界」から始まる部分であり、十八界のうちの眼界を論じる箇所の引用で あるが、現存『法蘊足論』における眼界についての記述は「云何眼界。謂 如眼根」（大正26・p.502c）となっているため、眼根についての個所を取 
り上げた。この点は、この箇所で論じられる問題の本質とはそれほど深く 関連しないため、これ以上言及しない。

『大毘婆沙論』が『法蘊足論』を引用して主張するのは、眼界には「地 獄、傍生、鬼、天、人の眼と、修所成の眼と、及び中有の眼」があるとい うことである。すなわち、地獄・傍生（畜生）・鬼（餓鬼）・天・人の五趣 とは別に、修所成や中有の眼があることが、ここで議論される問題の本質 に関わる部分である。

『大毘婆沙論』の当該箇所は「問一切中有為是趣攝非趣攝耶（一切の中 有は趣に属するのか、そうではないのか)」（大正 $27 \cdot \mathrm{p} .358 \mathrm{~b} ）$ という問 からはじまり、この問に対して「属する」と答えても、「属さない」と答 えても、誤りが生じると指摘する。ここで紹介される『法藴足論』は、も し中有が五趣に属するとした場合に、齟䶣をきたす文章の一例として紹介 されている。つまり『法蓝足論』当該箇所は、五趣の眼と別に中有の眼が あると説いているから、中有は五趣に属さないと理解していることを示し ている。『大毘婆沙論』はこの『法總足論』の一文以外にも、『施設足論』 や『品類足論』を提示し、中有が五趣に属すとすれば、それらとも矛盾が 生じると指摘している。

それでは中有が五趣に属さないとしたら、いかなる問題が生じるかとい えば、『大毘婆沙論』は尊者達羅達多の説と矛盾すると述べる。この説は 「中有趣向彼趣即彼趣攝（中有は、その趣に向からものであるから、その 趣に属するものである)」（大正 $27 \cdot \mathrm{p} .358 \mathrm{~b} ）$ というもので、明確に中有 は趣に属すると説いている。

結論を先取りすると『大毘婆沙論』は後者の説を採用する。そうなると、 尊者達羅達多説と矛盾が生じることになるが、これについてはどうするの かと問われると、「彼不須通非三藏故（それは、三蔵ではないから、会通 する必要はない)」（大正27・p.358b）と答えている。換言すると、『法蘊 足論』や『施設足論』『品類足論』が中有は五趣に属さないということの 証となっているのである。

この議論では中有が五趣に属すると主張する説についても、その根拠が 紹介されている。この説を主張するものたちは、『法蘊足論』との矛盾を 解消する必要がある。それについて、次のような説明がなされる。 


\section{『大毘婆沙論』（大正27・p.358b）}

問『法蓝論』説復云何通。

答『法蓝論』文應作是説。「地獄傍生鬼天人眼修所成眼。」不應復説 「及中有眼。」而復說者有別意趣。謂中有眼雖即趣攝以微細故復別 顯之。

\section{上記和訳}

問う、『法蓝足論』を、またどのように理解すべきであろらか。 答える、『法蘊足論』は次のように説くべきである。「地獄、傍生、 鬼、天、人の眼と、修所成の眼」と。そして「及び中有の眼」と説 くべきではない。しかし、そのように説くことには、別に意図があ るのである。すなわち中有の眼は趣に属するのであるが、微細なも のであるから、再び別にこれを示すのである。

中有が五趣に属すると主張する人々は、『法蘊足論』の所説には訂正の 余地があると指摘し、しかし、それを説くのは別に意図があると述べる。 その意図とは、中有の眼が微細なものであるから、趣に属するといえども、 別にこれを説くといらものである。

この指摘から、『法蓝足論』の当該箇所の文言は、中有が五趣に属する と主張する人々にとっても、そうでない人々にとっても、共通したもので あったことが理解できる。異読が存在しない故に、『法蘊足論』との矛盾 を指摘された人々は、その箇所には「別に意図がある」として、自説を正 当化しようとするのである。

なお、この議論は『俱舎論』にまで継承され、『法蓝足論』の当該箇所 の梵文を回収することもできる。これを紹介しておこう。

\section{『俱舎論』(大正 $29 \cdot p .42 a)$}

法蓝足論亦作是言。眼界云何。謂四大種所造淨色是眼。眼根眼處眼 界地獄傍生鬼人天趣修成中有。

\section{Abhidharmakośabhāśya of Vasubandhu (edited by P.Pradhan, Patna, 1967) p.114}


dharmaskandhe 'pi coktam “cakṣurdhātuh katamaḥ/ catvāri mahābhūtāny upādāya yo rūpaprasādaś cakṣuś cakṣur indriyam cakṣur āyatanam cakṣur dhātur nākas tairyagyonikam paitṛviṣayiko devyo mānuṣyako bhāvanāmayo 'ntarābhavikaś ce"ti/

なお『俱舎論』サンスクリットテキストにおいても『法蘊足論』の引用 が「眼界」の個所でなされていることから、現存漢訳の『法蓝足論』は省 略形の可能性がある。『俱舎論』の当該箇所でも『法藴足論』の一文は中 有が五趣と異なることを示すものとして用いられている。『法蘊足論』の この一文が、『大毘婆沙論』以降、中有と趣とが異なるものであることを 示す典拠として用いられてきた、と指摘することができよう。

\section{4-4. 用例(4)一四正断について一}

第四の用例は四正断についての言及である。

\section{『大毘婆沙論』(大正27・p.766a)}

問『法蘊』等論説。「斷已生惡不善法。即具四種。謂於已生惡不善 法為令斷故。生欲發懃攝持心者。彼斷已生惡不善位。亦能令彼惡不 善法未生不生。復令善法未生得生已生住等。乃至説修已生善法令安 住等亦具有四。謂於已生善法為令安住不忘倍修增廣故。生欲發懃攝 持心者。彼修已生諸善法位。亦能令彼惡不善法已生者斷。未生不生。 復令善法未生者生。如是便成十六正斷。」

\section{上記和訳}

問う、『法蓝足論』等の論は次のように説いている。「すでに生じた 悪・不善の法を斷じるために、四種を具える。すなわちすでに生じ た悪・不善の法を斷じるために、意欲を生じ、精進を發し、心を集 中させ、心を保つ者、彼はすでに生じた悪・不善の法を斷じ、また よく彼の悪・不善の法のいまだ生じていないものが生じることなく、 また善法のいまだ生じていないものを生じさせ、すでに生じたもの をとどめる等の四種である。そして、すでに生じた善法を修してと 
どめる等と説くことにも、また同様に四種が具わっているのである。 すなわち、すでに生じた善法をとどめて、忘れず、修めて、増大さ せるために、意欲を生じ、精進を發し、心を集中させ、心を保つ者、 彼はすでに生じた諸々の善法の位を修し、またよく彼の悪・不善の 法のですでに生じたものを斷じ、いまだ生じていないものを生じさ せず、また、善法のまだ生じていないものを生ぜじさせるのである。 このようにして、つまり十六正斷が成立するんのである」と

\section{『法藴論』該当箇所（大正26・p.4967c-a）}

有四正勝。何等為四。謂有苾媰。為令已生惡不善法斷故。起欲發勤 精進。策心持心。是名第一。為令未生惡不善法不生故。起欲發勤精 進。策心持心。是名第二。為令未生善法生故。起欲發勤精進。策心 持心。是名第三。為令已生善法堅住不忘脩滿倍增。廣大智作證故。 起欲發勤精進。策心持心。是名第四。

\section{上記和訳}

四正勝がある。どのようなものを四とするのであろうか。すなわち、 比丘がいて、すでに生じた悪・不善の法を断じるために、意欲を生 じ、精進を發し、心を集中させ、心を保つ。これを第一と名づける。 いまだ生じていない悪・不善の法を生じさせないために、意欲を生 じ、精進を發し、心を集中させ、心を保つ。これを第二と名づける。 いまだ生じていない善法を生じさせるために、意欲を生じ、精進を 發し、心を集中させ、心を保つ。これを第三と名づける。すでに生 じた善法を堅住し、忘れず、修し、満たして、倍増させ、広大にし 智によって体験するために、意欲を生じ、精進を發し、心を集中さ せ、心を保つ。これを第四と名づける。

『大毘婆沙論』一四一は、まず四念住について述心゙、その次に四正断に 言及する。ここに説かれる四正断は以下の通りである。

(1)すでに生じ悪や不善の法を断じるために意欲を生じ、精進を起し、心 を摂め、心を保つこと（於已生惡不善法為令斷故生欲發勒攝心持心） 
(2)いまだ生じていない悪や不善の法を断じるために、前と同様に行なら こと（於未生惡不善法為不生故餘説如）

(3)いまだ生じていない善の法を生じるために、前と同様に行ならこと (於未生善法為令生故餘説如前)

(4)すでに生じた善の法を安住させ、忘れず、倍修し、増広するために、 前と同様に行ならこと（於已生善法為令安住不忘倍修增廣故餘説如 前)、

『大毘婆沙論』が「『法藴足論』等」を引用して議論しているのは、四 正断の (1)を実践することは、四正断のすべてを具えていると指摘している。 言い換えると、すでに生じた悪を断じるためには、まずそのために意欲を 生じたり、精進したりする必要があるとともに、いまだ生じていない悪を 断じ、いまだ生じていない善を生じさせ、すでに生じた善を保持する必要 があるというのである。こう考えると四正断は一つの項目を行なうために 四つ凡てを実践することとなり、四つの項目に四つの実践の方法があると 考えると、計十六種の正断があると理解することができる。

それでは『大毘婆沙論』が示すこの理解は『法蘊足論』に基づいたもの かを考えてみよう。『法藴足論』における四正断は、上記に原文と示した 正勝品（『法蘊足論』三）に見出すことができる。ここでは『大毘婆沙論』 と同様の四つの項目を示し、その後に、その一つ一つを論じている。その 論じ方には一定の型があるが、それは『大毘婆沙論』の論じ方とは一致し ない。これは四正断の理解が『法蘊足論』の成立から、『大毘婆沙論』編 纂の間に変化したことを示唆するものである。

この変化を示唆するのは、論じ方の違いだけではなく『法蓝足論』が 「すでに生じた悪や不善」を五蓋と釈するのに対し、『大毘婆沙論』はこ れを悪と不善に分け、前者を有覆無記、後者を諸々の不善とそれぞれ釈し ている。これも四正断に対する理解の変化をらかがわせるものである3。

『大毘婆沙論』と『法藴足論』の四正断の理解は以上のような相違があ るが、『大毘婆沙論』は此処で指摘した理解を「『法藴足論』等」として引 用している点は注意が必要で、「等」とある以上は『法總足論』と共に何 等かの典拠に基づいて論を展開した可能性は否定できない。ここで指摘で きることは現存『法藴足論』の原文と『大毘婆沙論』の引用とが一致して 
いないといらことである。

またもう一点重要なことは『大毘婆沙論』が『法蘊足論』が「十六正 斷」を説くことを気にかけていることであり、『法藴足論』が十六正断を とくにのなぜ四正断とのみ説くのかと問らていることである。ここには 『法蓝足論』に対する一定の配慮があるということができよう。

\section{4-5. 用例(5)一天眼についての説明一}

第五の用例は天眼に関するものである。これは『大毘婆沙論』のみに見 られるもので、『阿毘曇毘婆沙論』はその対応箇所を欠いている。

\section{『大昆婆沙論』(大正27・p.766a)／『国訳大蔵経』毗曇部一四 p.310- 311}

『法蘊論』説。於眼周圍有時有分。色界大種所造天眼。清淨現前由 此天眼能見前後左右下上諸色差別。

見前後左右諸色者。非石壁等所障故。見下諸色者非地水等所障故。 見上諸色者。非雲霧等所障故。

\section{上記和訳}

『法藴論』は次のように説いている。「眼の周圍に於いて時有りて、 分有り、色界の大種所造の天眼の清淨なるもの現前す。此の天眼に 由りて能く前後・左右・下上 の諸色の差別を見る。」

前後・左右の諸色を見るとは、石壁等の障ゆる所に非らざるが故な り。下の諸色を見るとは、地水等の障ゆる所に非らざるが故なり。 上の諸色を見るとは、雲霧等の障ゆる所に非らざるが故なり。

\section{『法蘊論』該当箇所（大正 $26 \cdot p .490 c$ 。下線部は『大毘婆沙論』の 引用に相当する部分)}

能令證得殊勝智見者。云何名為殊勝智見。謂於此定。若習若修。若 多所作。至圓滿位。於舊眼邊。發起色界大種所造清淨天眼。依此天 眼。生淨眼識。依此眼識。能遍觀察前後左右上下諸色。如如色界大 種所造清淨天眼舊眼邊起。如是如是。生淨眼識。依此眼識。領受觀 察彼彼諸色。是名此中殊勝智見。 


\section{『法藴論』該当箇所（大正26・p.490c）}

「能く殊勝の智見を證得せしむとは、云何が名づけて殊勝の智見と 為すや。謂わく、此の定に於いて、若しは習じ、若しは修し、若し は多く所作して、圓滿位に至り、舊の眼邊に於いて、色界の大種所 造の清淨なる天眼を發起し、此の天眼に依りて淨眼識を生じ、此の 眼識に依りて、能く遍く前後・左右・上下の諸色を觀察し、色界の 大種所造の清淨なる天眼の、舊の眼邊に起るが如く如く、是くの如 く、是くの如く、淨眼識を生じ、此の眼識に依りて、彼彼諸の色を 領受・觀察する、是れを此の中の殊勝の智見と名づく。」

この『法蓝足論』の引用は『大毘婆沙論』一五○（根蓝触納息）に見ら れるものである。『大毘婆沙論』一四九の終わりから天眼と天耳について の様々な問答が見られる。これは『発智論』の本文の注釈ではなく、そこ から派生した『大毘婆沙論』独自の議論と指摘することができる ${ }^{4}$ 。当該 の引用は『大毘婆沙論』が『施設足論』における天眼説を紹介した後に表 われるものである。ここでは『大毘婆沙論』の引用文と『法總足論』の原 文が明確に一致していると判断し難いといら印象を与えるが、『国訳一切 経』の註（『国訳一切経印度撰述部 毗曇部 十四』pp.311-312。註29） を参考に、また『法蘊足論』の他所に同様の記述がないため、この箇所か らの引用と考えたい。

この引用のらち、どこまでが原文かがはっきりせず国訳一切経は「於眼 周圍有時有分」から「非雲霧等所障故」まです心゙てを引用と見なしている ようだが、原文と見なした個所と比較して「於眼周圍有時有分。色界大種 所造天眼。清淨現前由此天眼能見前後左右下上諸色差別」を『大毘婆沙 論』における『法蘊足論』の引用と考えたい。そうすると、この後につづ く「見前後左右諸色者。非石壁等所障故。見下諸色者非地水等所障故。見 上諸色者。非雲霧等所障故」といら一文は、『大毘婆沙論』編纂者が『法 蘊足論』の文章に与えた注釈と見なすのが自然であろら。このように考え ると、この引用は『法蓝足論』における天眼の説示を紹介するとともに、 その意味を明らかにしようとしたものと指摘することができる。 


\section{5. 小結}

本論文では『大毘婆沙論』における『法藴足論』の引用をすべて考察し た。その結果として以下の点を指摘することができよう。

（1)『大毘婆沙論』は『法蘊足論』をあまり引用しない

(2)引用される場合でも、何かを証明する典拠として用いられることは 少ない

（3) しかしながら『法蘊足論』に対する一定の配慮がある

『大毘婆沙論』における『法蘊足論』の引用を考察してわかることは、 まず『法蓝足論』の名称は他の六足論と比較すると現れる頻度が少なく、 また本文が引用される場合でも学説の紹介として用いられる場合が多く、 何かを証明する典拠として用いられることは少ない。唯一、中有と五趣と の関係を論じる場合に典拠として用いられている。また『大毘婆沙論』の 四正断の考察では、『法蘊足論』等の学説に一定の配慮がなされているよ らに感じられる。

このような現状から推察すると、『大毘婆沙論』編纂者たちにとって、 いわゆる六足論の中で、『法蘊足論』は最重要の典拠ではなかったといえ る。もちろんその存在は一定の役割を果たしたと思われるが、その学説が

『発智論』の注釈を通して有部の学説を再構成しようと意図した『大毘婆 沙論』編纂者たちに大きな影響を与えなかったと推測される。

本論文では『大毘婆沙論』において『法蘊足論』と明示される引用のみ を調査考察したゆえに、あるいは収集できなかった引用がまだある可能性 がある。今後は、その点について調查を進め、『大毘婆沙論』における 『法蓝足論』の役割を明らかにしたい。

\section{（大正大学綜合仏教研究所研究員）}

1 詳細な内訳は以下の通り。

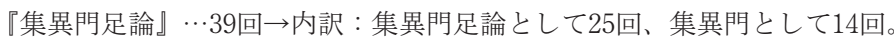

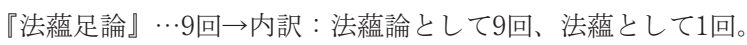




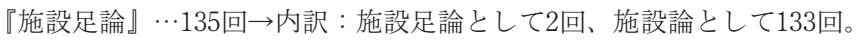

『識身足論』‥39回 $\rightarrow$ 内訳 : 識身足論として6回、識身論として29回、識身として5回。 『品類足論』 $\cdots 109$ 回 $\rightarrow$ 内訳 : 品類足論として36回、品類足として73回。

2 渡辺楳雄『有部阿毘達磨論の研究』(p.83) では、『大毘婆沙論』の引用回数につい て以下のように記している。

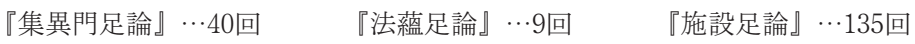

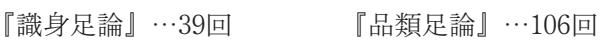

本研究は電子大蔵経を用いて引用を確認しており、渡辺の調査結果のうち『集異門足 論』と『品類足論』の引用回数を訂正すべきことが明らかになった。

3 『法藴足論』におけ四正断（四正勝）については田中教照『初期仏教の修行道論』 pp.232-234において論じられている。ここでは南伝『分別論』や『舎利弗阿毘量論』 と比較して、『法藴足論』が悪・不善法を五蓋とする解釈が独特のものであることが 指摘されている。

4 『国訳一切経印度撰述部 毗量部 十四』はこの議論について「発智論には、この議 論無く、唯、婆沙論にのみあるものにして所謂傍論なり」（p.301 脚注103）と指摘 している。 